\title{
PRELIMINARY REFERENCES, EFFECTIVE JUDICIAL PROTECTION AND STATE LIABILITY. WHAT \\ IF THE FERREIRA DA SILVA JUDGMENT \\ HAD NOT BEEN DELIVERED?
}

\author{
ALESSANDRA SILVEIRA' \\ SOPHIE PEREZ FERNANDES ${ }^{2}$
}

\author{
Cómo citar/Citation \\ Silveira, A. y Perez Fernandes, S. (2016). Preliminary References, Effective Judicial Protection \\ and State Liability. What if the Ferreira da Silva Judgment Had not Been Delivered? \\ Revista de Derecho Comunitario Europeo, 54, 631-666. \\ doi: http://dx.doi.org/10.18042/cepc/rdce.54.06
}

\begin{abstract}
The preliminary ruling mechanism was designed and actually revealed itself to be a structural tool in shaping the EU legal order. Mainly serving the correct and uniform interpretation and application of EU law, the mechanism also prevents rights conferred on individuals by EU law from being infringed. Focusing on this subjective dimension of the preliminary ruling mechanism, the present analysis concerns the compliance of the obligation to make a reference for a preliminary ruling laid down in Article 267(3) TFEU and the State liability emerging from the failure to comply with that obligation. This paper aims, first, to contextualize the recent ruling in the Ferreira da Silva case within some of the fundamentals of the ECJ's case-law, such as Van Gend \& Loos, Cilfit and Köbler. Our argument will lead us to consider another case that, like Ferreira da Silva, also took place before Portuguese courts but did not result in the same outcome due to the lack of a reference for a preliminary ruling made by the court adjudicating at last instance. The Santos Pardal case, in which the ECtHR delivered judgment forty days prior to the ECJ in Ferreira da Silva, allows
\end{abstract}

1 Associate Professor at the School of Law of the University of Minho (Portugal). Director of the Centre of Studies in European Union Law (CEDU) of the University of Minho. Jean Monnet Chair in European Union Law.

2 Assistant Lecturer at the School of Law of the University of Minho (Portugal). PhD Doctorate in European Union Law. 
us to infer what might have happened had no reference for a preliminary ruling been made in the latter. We will argue that, as a result, a flaw within the Union system of protection of fundamental rights is revealed — the lack of a specific proceeding to be triggered by individuals actively vigilant in protecting their rights when faced with the systematic unwillingness of the competent national courts to attend the questions of EU law at stake.

\section{Key words}

Preliminary references; State liability; effective judicial protection; fundamental rights.

\section{DECISIÓN PREJUDICIAL, TUTELA JUDICIAL EFECTIVA Y RESPONSABILIDAD DEL ESTADO. ¿̇Y SI LA SENTENCIA FERREIRA DA SILVA NO HABÍA SIDO PRONUNCIADA?}

\section{Resumen}

El mecanismo de decisión prejudicial fue diseñado y se reveló en realidad como una herramienta estructural en la configuración del ordenamiento jurídico de la Unión. Si sirve principalmente la uniforme interpretación y la correcta aplicación del derecho de la Unión, el mecanismo también evita que los derechos conferidos a los particulares por el derecho de la Unión sean infringidos. Centrándose en esta dimensión subjetiva del mecanismo de decisión prejudicial, el presente análisis se refiere al cumplimiento de la obligación de plantear una petición de decisión prejudicial previsto en el artículo 267(3) TFUE y la responsabilidad del Estado que surge de la falta de cumplimiento de esta obligación. El estudo tiene por objeto, en primer lugar, poner en contexto la reciente sentencia en el caso Ferreira da Silva dentro de algunos de los pronunciamentos fundamentales de la jurisprudencia del Tribunal de Justicia, como Van Gend \& Loos, Cilfit y Köbler. Nuestro argumento nos llevará a considerar otro caso que, como Ferreira da Silva, también se llevó a cabo ante los tribunales portugueses, pero no dio lugar a los mismos resultados debido a la falta de una petición de decisión prejudicial planteada por el órgano jurisdiccional que conoce en última instancia. El caso Santos Pardal, en la que el TEDH dictó sentencia cuarenta días antes del Tribunal de Justicia en Ferreira da Silva, nos permite inferir lo que podría haber ocurrido si ninguna petición de decisión prejudicial habia sido planteada en el último. Vamos a argumentar que, como resultado, una falla en el sistema de protección de los derechos fundamentales de la Unión se revela - la falta de un procedimiento específico para ser activado por particulares activamente vigilantes en la protección de sus derechos ante la sistemática falta de voluntad de las jurisdicciones nacionales para plantear las cuestiones de derecho de la Unión pertinentes. 


\section{Palabras clave}

Decisión prejudicial; responsabilidad del Estado; tutela judicial efectiva; derechos fundamentales.

\section{RENVOI PRÉJUDICIEL, PROTECTION JURIDICTIONNELLE EFFECTIVE ET RESPONSABILITÉ DE L'ÉTAT. ET SI L'ARRET FERREIRA DA SILVA N'AVAIT PAS ÉTÉ PRONONCÉE?}

\section{Résumé}

Le mécanisme du renvoi préjudiciel a été conçu et s'est révélé comme étant un outil structurel dans la formation de l'ordre juridique de l'Union. Servant principalement à l'interprétation et à l'application correcte et uniforme du droit de l'Union, le mécanisme empêche également que les droits conférés aux particuliers par le droit de l'Union soient violés. En mettant l'accent sur cette dimension subjective du mécanisme du renvoi préjudiciel, la présente analyse se concentre sur le respect de l'obligation de renvoi prévue à l'article 267(3) TFUE et sur la responsabilité des États membres qui résulte du non-respect de cette obligation. L'article vise, en premier lieu, à contextualiser la récente décision dans l'affaire Ferreira da Silva au sein de certains arrêts fondamentaux de la jurisprudence de la Cour de Justice, tels que Van Gend \& Loos, Cilfit et Köbler. Notre argumentation va nous conduire à envisager une autre affaire qui, comme Ferreira da Silva, a également eu lieu devant les tribunaux portugais, mais sans aboutir au même résultat en raison de l'absence de renvoi préjudiciel par la juridiction statuant en dernière instance. L'affaire Santos Pardal, dans laquelle la CEDH a rendu son jugement quarante jours avant la Cour de Justice dans l'affaire Ferreira da Silva, nous permet de déduire ce qui aurait pu se produire si aucun renvoi préjudiciel n'aurait été fait dans cette dernière affaire. Nous soutenons que, par conséquent, un défaut dans le système de protection des droits fondamentaux de l'Union se révèle - l'absence d'une procédure spécifique susceptible d'être déclenchée par les particuliers activement vigilants dans la protection de leurs droits lorsqu'ils sont confrontés à la réticence systématique des juridictions nationales à examiner les questions de droit de l'Union en jeu.

\section{Mots clés}

Renvoi préjudiciel; responsabilité de l'État; protection juridictionnelle effective; droits fondamentaux. 


\section{SUMMARY}

I. INTRODUCTION. II. GENERAL REMARKS: A SUBJECTIVE READING OF THE PRELIMINARY RULING MECHANISM. III. THE FERREIRA DA SILVA CASE: 1. Ferreira da Silva in light of Cilfit - its implications on the obligation to make a reference for a preliminary ruling laid down in Article 267(3) TFEU; 2. Ferreira da Silva in light of Köbler - its implications on the State liability regime in case of breach of EU law by a national court adjudicating at last instance; 3 . What if the Ferreira da Silva judgment had not been delivered? The Santos Pardal judicial saga. IV. FINAL REMARKS.

\section{INTRODUCTION}

In just over a month, the Portuguese legal regime for the non-contractual civil liability of the State for damages caused in the exercise of the judicial function was the subject of two different judgments, one from the European Court of Human Rights (ECtHR) and the other from the European Court of Justice (ECJ). In its judgment of 9 September 2015 in the Ferreira da Silva $\mathrm{case}^{3}$, the ECJ deemed for the first time that a supreme national court had not complied with its obligation to make a reference for a preliminary ruling under Article 267(3) TFEU. The main proceedings concerned a liability action brought against the Portuguese State founded on breaches of EU law attributable to the Supremo Tribunal de Justiça (Supreme Court of Justice). Thus, the ECJ was also faced with the Portuguese regime governing State liability applicable to actions for damages caused in the exercise of the judicial function. The Ferreira da Silva judgment was preceded by about forty days by the judgment of the ECtHR of 30 July 2015 in the Santos Pardal case ${ }^{4}$ that likewise relates to the way in which the Supremo Tribunal de Justiça deals with questions of EU law, with its obligation to make a reference for a preliminary ruling to the ECJ, and to the State liability emerging from the failure to comply with that obligation.

The EU law issues underlying both cases are different: the Santos Pardal case raised questions concerning the interpretation of the Directive 90/232

\footnotetext{
3 Judgment of the Court in Ferreira da Silva, C-160/14, EU:C:2015:565.

4 Ferreira Santos Pardal v. Portugal, 30 July 2015, no. 30123/10.
} 
relating to insurance against civil liability in respect of the use of motor vehicles $^{5}$, and the Ferreira da Silva case raised issues concerning the interpretation of the Directive 2001/23 relating to the safeguarding of employees' rights in the event of transfers of undertakings, businesses or parts of undertakings or businesses ${ }^{6}$. What unfortunately unites them is the fact that the Supremo Tribunal de Justiça held the Law no. 67/2007, which lays the currently in force non-contractual civil liability of the State and other public bodies' regime (henceforth, RRCEE) ${ }^{7}$, the «alpha and omega» of the State liability for damages caused in the exercise of the judicial function in disregard of the relevant ECJ case-law on the matter - as we shall see throughout this text. Both judgments provide eminent examples that the dialogue between national courts and the ECJ through the preliminary ruling mechanism is not only imperative for determining the exact content of the legal framework applicable in a context of legal pluralism, but also as a guarantee that the subjective claims of the individuals are handled in compliance with the relevant EU law.

\section{GENERAL REMARKS: A SUBJECTIVE READING OF THE PRELIMINARY RULING MECHANISM}

If one of the secrets «of the Rule of Law in the legal order of the European Union rests (...) in the genius of the Preliminary Reference procedure», it is not only because it provides with an instrument designed to ensure uni-

5 Third Council Directive 90/232/EEC of 14 May 1990 on the approximation of the laws of the Member States relating to insurance against civil liability in respect of the use of motor vehicles (OJ L 129, 19.5.1990, p. 33-35). The five directives on the matter were codified in the Directive 2009/103/EC of the European Parliament and of the Council of 16 September 2009 relating to insurance against civil liability in respect of the use of motor vehicles, and the enforcement of the obligation to insure against such liability (OJ L 263, 7.10.2009, p. 11-31).

6 Council Directive 2001/23/EC of 12 March 2001 on the approximation of the laws of the Member States relating to the safeguarding of employees' rights in the event of transfers of undertakings, businesses or parts of undertakings or businesses (OJ L 82, 22.3.2001, p. 16-20).

7 The Regime da Responsabilidade Civil Extracontratual do Estado e demais entidades públicas was approved by the Law no. 67/2007 of 31 December and altered by the Law no. 31/2008 of 17 July.

8 J.H.H. WEILER, «Revisiting Van Gend en Loos: Subjectifying and Objectifying the Individual», in Antonio TIZZANO et al. (org.), 50th Anniversary of the Judgment in Van Gend en Loos 1963-2013, Conference proceedings, Court of Justice of the 
formity in the application of EU law, but also because it provides a means of indirect access by individuals to the ECJ. It is not particularly hard to understand that a legal system that binds and holds together 28 normative/ doctrinal/jurisprudential traditions, with differences sometimes very marked, may only work if its provisions - furthermore drafted and equally binding in 24 different official languages - receive a uniform interpretation, regardless of the national contexts in which they ought to be applied. It is the imperative of equality of individuals before the law which requires it. EU law is to be applied at the same time and with equal effect throughout the Union for it is the only way to ensure that the protection of rights conferred by it on individuals does not vary from Member State to Member State.

For that purpose, the preliminary ruling mechanism establishes an «effective cooperation between the Court of Justice and national courts» designed to «ensure the utmost uniformity in the application of (Union) law»", thus preventing the spread of differences in a decentralized judicial system. But aside from this objective function, the mechanism also operates as a tool to eliminate the obstacles that undermine the full enjoyment of the rights that EU law grants to individuals. Considering the limited access to the ECJ granted to individuals, which is, moreover, non-existent with regard to the actions of Member States, national courts sought for by individuals concerned to protect their rights become the «keystone of the European Union judicial system $»^{10}$ and the preliminary ruling mechanism, although «based on a dialogue between one court and another $»^{11}$, reveals itself as an instrument for the effective judicial protection of individuals ${ }^{12}$.

European Union, 2013, p. 21, available at curia.europa.eu/jcms/jcms/P_95693/ (last accessed on 28.6.2016).

9 Judgment of the Court in Busseni, C-221/88, EU:C:1990:84, para 13.

10 European Parliament resolution of 9 July 2008 on the role of the national judge in the European judicial system, OJ C 229E, 3 december 29, p. 27, para 1.

11 Judgment of the Court in Kempter, C-2/06, EU:C:2008:78, para 42.

12 On the dual function of the preliminary ruling mechanism, both «au service de l'unité du droit communautaire» and «au service de la protection juridictionnelle des particuliers», Olivier DUBOS, Les juridictions nationales, juge communautaire. Contribution à l'étude des transformations de la fonction juridictionnelle dans les États membres de l'Union européenne, Dalloz, Paris, 2001, pp. 73-120. On the subjective dimension of the preliminary ruling mechanism, Inês de QUADROS, A função subjectiva da competência prejudicial do Tribunal de Justiça das Comunidades Europeias [The subjective function of the preliminary competence of the Court of Justice of the European Communities], Almedina, Coimbra, 2007. 
Thus, «(the) vigilance of individuals concerned to protect their rights amounts to an effective supervision in addition to the supervision entrusted by Articles 169 and 170 to the diligence of the Commission and of the Member States» ${ }^{13}$. So reads the famous Van Gend \& Loos ruling, one of the ECJ's first «hits» ${ }^{14}$. Decades before the affirmation of the Community as a "Community based on the rule of law» ${ }^{15}$ and the formal establishment of the European citizenship which "places the individual at the heart of its activities» ${ }^{16}$, the iconic ruling had already placed the individuals at the centre of the European legal construction and entrusted them with an active role in guaranteeing the rule of law within the Union. The characterization of individuals as subjects of the (then) Community legal order has, as Pierre Pescatore ${ }^{17}$ explained, an underlying "certaine idée d'Europe» based on a democratic ideal that goes far beyond the participatory mechanisms laid down in the Treaties. From Community, now Union law, arises, not only duties, but also rights «which become part of their legal heritage.» The ruling further clarifies that «[these] rights arise not only where they are expressly granted by the Treaty, but also by reason of obligations which the Treaty imposes in a clearly defined way upon individuals as well as upon the Member States and upon the institutions of the Community» ${ }^{18}$

The course of time proved that the «vigilance of individuals concerned to protect their rights» became one driving force of the European integration process. In this regard, former President of the ECJ Robert Lecourt stated: «la crainte des recours individuels est [...] le commencement de la sagesse communautaire» ${ }^{19}$. It is undeniable how much private litigation played a fundamental role throughout the integration process, bringing to light, through

13 Judgment of the Court in Van Gend \& Loos, 26/62, EU:C:1963:1, p. 13.

14 See Bruno DE WITTE, "The Continuous Significance of Van Gend en Loos", in Miguel POIARES MADURO and Loïc AZOULAI (coord.), The Past and Future of EU Law. The Classics of EU Law Revisited on the 50th Anniversary of the Rome Treaty, Hart Publishing, Oxford, 2010, p. 9.

15 Judgment of the Court in «Les Verts», 294/83, EU:C:1986:166, para 23.

16 See the second paragraph of the Preamble of the Charter of Fundamental Rights of the European Union (henceforth, CFREU).

17 Pierre PESCATORE, «The Doctrine of 'Direct Effect': An Infant Disease of Community Law», ELRev, no. 8, 1983, pp. 157-158.

18 Van Gend \& Loos, cit., note 11, p. 12.

19 Robert LECOURT, «Quel eut été le droit des Communautés sans les arrêts de 1963 et 1964?», in L'Europe et le Droit - Mélanges en hommage à Jean Boulouis, Dalloz, Paris, 1991, p. 352 («fear of individual actions is [...] the beginning of Community wisdom»). 
the preliminary ruling mechanism, dimensions at first sight unseen of EU law and of the system of the Treaties itself. Without the former, meaningful contributions resulting from the preliminary ruling mechanism would have been lost and a gap would exist that neither the diligence of the Commission nor of the Member States would have fulfilled. A paradigmatic example of this is provided by the principle of State liability for breaches of EU law. Absent from the wording of the Treaties, the principle was revealed by the Francovich ruling, which resulted from two Italian references for a preliminary ruling, as being «inherent in the system of the Treaty» ${ }^{20}$. From Francovich emerges an additional supervision mechanism entrusted to individuals concerned to protect their rights. The principle of State liability for breaches of EU law became a fundamental tool at the disposal of individuals to protect their rights granted by EU law and also contributes to guaranteeing the rule of law within the Union. Liability actions brought against Member States for breaches of EU law offer the chance to individuals to play an active role as guarantees of the compliance of EU law by national authorities.

To paraphrase the words of Robert Lecourt, fear of individual actions should have been the beginning of national wisdom as well. In some cases, it was; in others, not so much. In a system of public protection of individual rights (in contrast with the private protection of rights), the «vigilance of individuals concerned to protect their rights» can only operate through public authorities, either administrative or judicial. Within the Union, the vigilance of individuals concerned to protect their rights mainly operates through national authorities - that is the genetic code of the European integration process. Problems arise when said vigilance depends on the willingness of the competent national authorities and, in particular, that of national courts to make a reference to the ECJ for a preliminary ruling under Article 267 TFEU. Where this willingness is nonexistent, private vigilance cannot operate. This is particularly harmful when the unwillingness comes from a national court against whose decisions there is no judicial remedy under national law and, thus, under the obligation to make a reference for a preliminary ruling [Article 267(3) TFEU].

Albeit indirectly, the ruling in Ferreira da Silva proves this point, especially when considered together with the Santos Pardal ruling. Disregarding the material problem at stake, and after describing the underlying judicial saga (i), this text aims at assessing the implications that the Ferreira da Silva ruling has in terms of the preliminary ruling mechanism (ii) and for the establishment of State liability for breaches of EU law (iii). This ruling comes

20 Judgment of the Court in Francovich, C-6/90 and C-9/90, EU:C:1991:428, para 35. 
in line with the ECJ case-law settled in Cilfit ${ }^{21}$ and Köbler ${ }^{22}$. Finally, it also assesses what consequences there would be for the effective judicial protection of the rights of the affected individuals had no request for a preliminary ruling been made in the Ferreira da Silva case (iv). Unfortunately, as the Santos Pardal case demonstrates, the question is not merely hypothetical.

\section{THE FERREIRA DA SILVA CASE}

The facts of the main proceedings took place in $1993^{23}$ and concerned the dissolution of a company. After the dissolution, ninety-seven workers brought proceedings to challenge the collective redundancy. These proceedings first took place before the Tribunal de Trabalho de Lisboa (Lisbon Labour Court), and were subject to an appeal before the Tribunal da Relação de Lisboa (Lisbon Court of Appeal) and then (an appeal of cassation) before the Supremo Tribunal de Justiça (Supreme Court of Justice). Some of the applicants asked the latter to make a reference for a preliminary ruling to the ECJ. The problem concerned the interpretation of the concept of 'transfer of a business' within the meaning of the Directive 2001/2324. The Supremo Tribunal de Justiça denied the requests considering that there were no questions regarding the interpretation of the relevant provisions of EU law that could justify the reference for a preliminary ruling ${ }^{25}$.

The reasoning of the Supremo Tribunal de Justiça was based on the Cilfit ruling. The Portuguese supreme court initially recognised that the obligation to make a reference for a preliminary ruling under Article 267(3) TFEU only exists when national courts adjudicating at last instance consider that «recourse to $[\mathrm{EU}]$ law is necessary in order to resolve the dispute before them and, in addition, a question concerning the interpretation of that law has arisen ${ }^{26}$. However, as the Supremo Tribunal de Justiça also mentioned, even when those circumstances are met, that obligation is not limitless. By mentioning again the ruling on Cilfit, the Portuguese court highlighted that "(the) Court of Justice itself has expressly recognised that the correct application of

\footnotetext{
21 Judgment of the Court in CILFIT, 283/81, EU:C:1982:335.

22 Judgment of the Court in Köbler, C-224/01, EU:C:2003:513.

23 Ferreira da Silva, cit., note 3, para 8-19.

24 See Art. 1(1) of Directive 2001/23.

25 See Judgment of the STJ of 25.2.2009, Case 08S2309, para 3.7, available at www. dgsi.pt (last accessed on 28.6.2016) with some transcribed excerpts in Ferreira da Silva, cit., note 3, para 16-18.

26 Ferreira da Silva, cit., note 3, para 16.
} 
[EU] law may be so obvious as to leave no scope for any reasonable doubt as to the manner in which the question raised is to be resolved, thus removing the obligation to make a reference for a preliminary ruling in that situation too ${ }^{27}$. Taking into consideration (i) the features of the case, (ii) the content of the provisions of EU law cited by the applicants, (iii) the interpretation of those provisions by the ECJ's settled case-law and (iv) that the Directive at issue already gave effect to the consolidation of the relevant concepts which that same case-law had brought about, the Supremo Tribunal de Justiça concluded that those concepts were «so clear in terms of their interpretation in case-law», both European and national/Portuguese, that there was no material doubt as to interpretation which would make a reference for a preliminary ruling necessary ${ }^{28}$. Additionally, the Supremo Tribunal de Justiça considered that one of the questions suggested by the plaintiffs could not be addressed to the ECJ as it concerned the compatibility of a provision of Portuguese law with the Directive at stake, an issue for which the ECJ has no jurisdiction.

Unsatisfied, the applicants brought proceedings regarding the non-contractual civil liability of the State arguing that, in its decision of 25 February 2009, the Supremo Tribunal de Justiça (i) had erroneously interpreted the concept of 'transfer of a business' within the meaning of the Directive 2001/23 and (ii) had not made a reference for a preliminary ruling to the ECJ when such a reference was mandatory under Article 267(3) TFEU $^{29}$. In the liability proceedings, the Portuguese State argued that, under Article 13(2) of the above mentioned RRCEE, a claim for damages must be based on the prior setting aside, by the court having jurisdiction, of the decision that caused the loss or damage. Therefore, as the decision of the Supremo Tribunal de Justiça had not been set aside, the damages sought were not payable ${ }^{30}$.

These proceedings were carried out before the Varas Civeis de Lisboa (Civil Courts of Lisbon) that, considering the issues raised, decided to stay the proceedings and to make a reference for a preliminary ruling. The ECJ was, therefore, given the opportunity to clarify the concept of 'transfer of a business' within the meaning of the Directive 2001/23 ${ }^{31}$, but also to offer further explanation on (i) the obligation for national courts adjudicating at last instance to make a reference for a preliminary ruling under Article 267(3) TFEU and (ii) the compatibility with the principles of Union law concerning

\footnotetext{
Ibid, para 17.

Ibid, para 17-18.

29 Ibid, para 19.

30 Ibid, para 7 and 20.

31 Ibid, para 23-35.
} 
State liability for breaches of EU law of a rule such as the rule enshrined in Article 13(2) RRCEE ${ }^{32}$.

The Varas Civeis de Lisboa found themselves in the same situation as the Landesgericht für Zivilrechtssachen Wien in the Köbler case and the Tribunale di Genova in the Traghetti del Mediterraneo case ${ }^{33}$ and actually followed their example. Their initiative not only allowed to avoid the risk of errors in assessing the breach of EU law attributable to a Member State [that was the non-compliance by the Supremo Tribunal de Justiça of its obligation to make a reference for a preliminary ruling under Article 267(3) TFEU], but also to clarify the legal framework applicable to State liability in the case at hands [by setting aside the rule of Article 13(2) RRCEE due to its incompatibility with the principle of effectiveness].

\section{FERREIRA DA SILVA IN LIGHT OF CILFIT — ITS IMPLICATIONS ON THE OBLIGATION TO MAKE A REFERENCE FOR A PRELIMINARY RULING LAID DOWN IN ARTICLE 267(3) TFEU}

In regard to the first issue — the obligation to make a reference for a preliminary ruling by national courts adjudicating at last instance - , the ECJ's answer was based on its case-law since the Cilfit ruling. As Advocate General Yves Bot mentioned in his Opinion, "[where] there is a dispute that raises a question concerning the interpretation of EU law, the discharge by a national court or tribunal against whose decisions there is no judicial remedy under national law of its obligation to make a reference to the Court thus constitutes the rule, while a decision not to make a reference is the exception». That is the reason why the Cilfit ruling "places on national courts and tribunals adjudicating at last instance an enhanced duty to state reasons where they refrain from referring questions to the Court. ${ }^{34}$

The contours of the Cilfit ruling are well known ${ }^{35}$. Here, the ECJ clarified the scope of the obligation for national courts adjudicating at last instance to make a reference for a preliminary ruling regarding a question of interpretation of EU law under Article 267(3) TFEU. A decision not to make a reference may be taken if $(i)$ the question of EU law raised is irrelevant, (ii)

32 Ibid, para 22.

33 Judgment of the Court in Traghetti del Mediterraneo, C-173/03, EU:C:2006:391.

34 Opinion of Advocate General Bot in Ferreira da Silva, C-160/14, EU:C:2015:390, para 89-90.

35 But not necessarly flawless - see particularly Peter J. WATTEL, «Köbler, CILFIT and Welthgrove: We can't go on meeting like this», CMLRev, no. 41, 2004, pp. 177-190. 
the provision of EU law in question has already been interpreted by the ECJ, or (iii) the correct application of EU law is so obvious as to leave no scope for any reasonable doubt ${ }^{36}$. Each of these three criteria - relevancy, prior ECJ ruling and acte clair - are not uncontroversial and, if properly considered, far from constituing an arbitrary scheme that allows national courts to wash their hands of their obligation to make a reference for a preliminary ruling, instead reinforces their role as EU courts of general jurisdiction ${ }^{37}$, for it makes them "delegates of the ECJ for the application of [EU] law» ${ }^{38}$. As for the Ferreira da Silva case in particular, the decision of the Supremo Tribunal de Justiça to not make a reference for a preliminary ruling was based on both the prior ECJ ruling criteria and the acte clair doctrine ${ }^{39}$.

The prior ECJ ruling criteria is due to the authority of the precedent that arises from the Court's decisions under Article 267 TFEU. The ECJ had previously established in Da Costa that «the authority of an interpretation under Article [267 TFEU] already given by the Court may deprive the obligation of its purpose and thus empty it of its substance», that being the case "when the question raised is materially identical with a question which has already been the subject of a preliminary ruling in a similar case» ${ }^{40}$. In Cilfit the hypothesis was extended also "where previous decisions of the Court have already dealt with the point of law in question, irrespective of the nature of the proceedings which led to those decisions, even though the questions at issue are not strictly identical $\aleph^{41}$. In both rulings, the ECJ noted that national courts, including those adjudicating at last instance, remain nevertheless «entirely at liberty to bring a matter before the Court of Justice if they consider it appropriate to do so» ${ }^{42}$. The binding precedent system thus established both confirms that the $\mathrm{ECJ}$ is the paramount interpreter of EU law and leaves national courts with some degree of autonomy to give judgment on their own authority when a question of interpretation of EU law is raised. The authoritative nature of the

36 Cilfit, cit, note 21, para 21.

37 Judgment of the General Court, T-51/89, Tetra Pak, EU:T:1990:41, para 42.

38 See Paul Craig, "The Classics of EU Law Revisited: CILFIT and Foto-Frost», in Miguel POIARES MADURO and Loïc AZOULAI (coords.), The Past and Future of EU Law. The Classics of EU Law Revisited on the 50th Anniversary of the Rome Treaty, Hart Publishing, Oxford, 2010, pp. 185-189.

39 As in the Ferreira da Silva case the EU law issue raised concerned the interpretation of a provision of EU law, the reference for a prelimanry ruling concerning the validity of secondary provisions of EU law will not, henceforth, be considered.

40 Judgment of the Court in Da Costa, 28 to 30/62, EU:C:1963:6, para 3.

41 Cilfit, cit, note 21, para 14.

42 Ibid, para 15, and Da Costa, cit., note 40, para 5. 
Court's decisions under Article 267 TFEU is enhanced, as they project an erga omnes effect to all national courts, without preventing the latter from seeking enlightment from the ECJ in case of remaining interpretative doubts. According to the prior ECJ ruling criteria, whenever the question of interpretation of EU law arising from a specific case pending before a national court adjudicating at last instance is materially identical to another which had already been the object of a previous ruling from the ECJ, the Court having therefore already provided for an interpretation, the purpose of guaranteeing the proper and correct interpretation and application of EU law under Article 267(3) TFEU is safeguarded without needing further intervention of the ECJ, provided that the prior ruling clarified the point of law in question and dispelled any interpretative doubts of the national court.

In turn, the acte clair doctrine allows national courts adjudicating at last instance not to make a reference for a preliminary ruling even without a previous ruling from the ECJ. But, in order to find an acte clair, the correct application of EU law must be «so obvious as to leave no scope for any reasonable doubt as to the manner in which the question raised is to be resolved»; and to reach this conclusion, "the national court or tribunal must be convinced that the matter is equally obvious to the courts of the other Member States and to the Court of Justice.» In order to prevent the arbitrary use of this possibility of exemption from the obligation to make a reference for a preliminary ruling under Article 267(3) TFEU, the ECJ framed the acte clair doctrine with several precautions in order to be used reasonably and with prudence. Under the Cilfit case-law, several conditions must be met before a national court may conclude to be in the presence of an acte clair and, thus, legitimately refrain from referring to the ECJ. The national court must assess the risks of its decision to not make a reference for a preliminary ruling, especially bearing in mind the specific characteristics of EU law, the particular difficulties of its interpretation and the risk of divergence in judicial decisions within the Union. Those characteristics, difficulties and risks mainly relate to the different language versions in which EU law provisions are drafted and equally binding, to the peculiar terminology and legal concepts used in EU law, the meanings of which may not necessarily be the same between Member States and between national law and EU law, and to the necessity to carry out a systematic and teleological interpretation of EU law provisions ${ }^{43}$. The acte clair test, if properly applied, may seldom succeed. It requires an ideal European judge: deeply rooted in all EU law matters, if not legally omniscient,

43 Cilfit, cit., note 21, para 16-21, and Judgment of the Court in Intermodal, C-495/03, EU:C:2005:552, para 33, as well as Ferreira da Silva, cit., note 3, para 38-39. 
and considering the successive enlargements, increasingly multilingual. As the acte clair doctrine implies the risk of overriding the obligation to refer specified in Article 267(3) TFEU, the ECJ surrounded it «in such a qualified and watered-down form that it is questionable whether the Court was not also seeking simultaneously to destroy its substance» ${ }^{44}$. The strategy was then to neutralize, in practice, the exception ${ }^{45}$ in order to avoid its arbitrary use by national courts, especially national supreme courts.

Both hypotheses for exemption from the obligation to make a reference for a preliminary ruling analysed are based on the ideia that the cooperation between the ECJ and national courts does not deprive the latter from their faculty to, as bodies of a judicial nature, appreciate and decide on the convenience of submitting a question for a preliminary ruling. Both criteria allow national courts adjudicating at last instance to sort out the questions that correspond to real doubts about the interpretation of a provision of EU law. They would otherwise become mere judicial mailboxes ${ }^{46}$ automatically referring to the ECJ under Article 267(3) TFEU. If the interpretative doubt raised in a specific case has already been clarified in previous case-law from the ECJ or if it were to indeed concern an acte clair, the reference for a preliminary ruling would be superfluous and even counter-productive as it would involve unnecessary costs and delays for litigants and would contribute to the saturation of the workload of the ECJ.

The conditions under which those criteria may legitimately be resorted to by national courts adjudicating at last instance highlight that a decicion to not make a reference for a preliminary ruling under Article 267(3) TFEU ought to be the result of a weighted judgment that concludes that consultation with the ECJ is unnecessary to ensure proper and uniform application of EU law. Thus, those conditions reinforce their role as EU courts of general jurisdiction. As Advocate General Stix-Hackl explained regarding the acte clair doctrine specifically, "[the] requirements laid down in the judgment in Cilfit are intended [...] to encourage the national court not to assume rashly — that is to say not simply from its own perspective and on the basis of the wording of the provision submitted to it - that the interpretation of a Community provision is 'unequivocal'. They are intended to alert the national court to the

44 Jo SHAW, Law of the European Union, Palgrave Law Masters, 2000, p. 410.

Daniel SARMIENTO, Poder Judicial e Integración Europea. La construcción de un modelo jurisdiccional para la Unión, Civitas Ediciones, Madrid, 2004, p. 98.

46 Francisco PEREIRA COUTINHO, Os tribunais nacionais na ordem jurídica da Uniāo Europeia. O caso português [National courts in the legal order of the European Union. The Portuguese case], Coimbra Editora, Coimbra, 2013, p. 210. 
specific characteristics of Community law, thus cautioning it against hasty or one-sided conclusions and, therefore, steering it towards a 'considered certainty'. This 'certainty' is to be that of an expert who approaches the examination of the question of Community law as one acquainted with the fundamental characteristics of that law» ${ }^{47}$. The aim of those requirements is to safeguard the possibility that national courts adjudicating at last instance, when considering not to refer to the ECJ, embrace their clothes as judges of the Union and internalize in their decision the consequences it may have for the consistency and the integrity of EU law ${ }^{48}$. However, as steely ${ }^{49}$ as those requirements may be, they are not sufficient to remove all subjectivity: assessing the clarity of an act is not only isolated, as it is made solely by and for the national court concerned, but also subjective as it is based on its own criteria of interpretation. This degree of subjectivity carries the risks of jurisprudential differences within each Member State and between Member States. That is precisely the issue raised in Ferreira da Silva.

In the Ferreira da Silva case, the Supremo Tribunal de Justiça took into consideration in its analysis case-law from the ECJ regarding the interpretation of the concept of 'transfer of a business' ${ }^{50}$, as well as the relevant provisions of the Directive 2001/23. However, the analysis of previous rulings from the ECJ was neither detailed nor exhaustive - the comparative consideration of the abundant case-law mentioned in the Ferreira da Silva judgment is illustrative ${ }^{51}$. Additionaly, no comparative analysis nor any comparison of different language versions were carried out. Considerations concerning the obligation to make a reference for a preliminary ruling under Article 267(3) TFEU are rather laconic. The Supremo Tribunal de Justiça concluded that the interpretation of the concept of 'transfer of a business' did not leave scope for any reasonable interpretative doubt with no considered certainty in the sense explained above and without internalizing in its decision not to refer to the ECJ the consequences it might have for the consistency and the integrity of EU law.

47 Opinion of Advocate General Stix-Hackl in Intermodal, C-495/03, EU:C:2005:215, para 102 (emphasis added).

48 Reaching the same conclusion, PEREIRA COUTINHO, op. cit., note 46, pp. 199217.

49 By reference to SARMIENTO, op. cit., note 45, p. 98, who characterizes the requirements as «un listado bastante férreo».

50 In particular, Judgments of the Court in Carlito Abler, C-340/01, EU:C:2003:629, and in Güney-Görres, C-232/04 and C-233/04, EU:C:2005:778.

51 Ferreira da Silva, cit., note 3, para 23-35. 
This also follows from the Ferreira da Silva ruling, especially if considered in conjunction with the judgment delivered by the ECJ on the same day in the case $X^{52}$. Here, the ECJ was asked whether a court adjudicating at last instance, which considers that the application of EU law is so obvious as to leave no scope for any reasonable doubt, is required to make a reference for a preliminary ruling under Article 267(3) TFEU when a lower national court has already made a reference in a similar case and with the same legal issue. In both the $X$ and the Ferreira da Silva rulings, the ECJ reiterated that on national courts adjudicating at last instance falls the «sole responsibility for determining whether the correct application of EU law is so obvious as to leave no scope for any reasonable doubt and for deciding, as a result, to refrain from referring to the Court a question concerning the interpretation of EU law which has been raised before it " ${ }^{53}$. Therefore, it is for the national courts adjudicating at last instance «alone» to take «upon themselves and independently the responsibility for determining whether the case before them involves an 'acte clair' " ${ }^{54}$. So, if a lower court has referred a question to the ECJ for a preliminary ruling, «that fact alone does not preclude the supreme court of a Member State from concluding, from its examination of the case and in keeping with the criteria laid down in the judgment in Cilfit [...], that the case before it involves an 'acte clair'», thus refraining itself from making a reference to the ECJ, nor is it «required to wait until the Court of Justice has given an answer to the question referred for a preliminary ruling by the lower court» ${ }^{55}$.

One of the referring courts in the $X$ case was the Hoge Raad der Nederlanden (Supreme Court of the Netherlands). In its ruling, the ECJ clarified that the existence of contradictory rulings was not a decisive enough element to trigger the obligation under Article 267(3) TFEU. As the ECJ further explains in Ferreira da Silva, a national court adjudicating at last instance may understand that the interpretation that it proposes to give a certain provision of EU law is the correct one without giving rise to any reasonable doubt, even if it differs from the one given by inferior courts ${ }^{56}$. Here, the ECJ seeks to maintain a cooperative relationship with national supreme courts and confirms the deference approach and the trust placed in them inherent to the acte clair doctrine. This approach, however, is confined to situations characterised

52 Judgment of the Court in X, C-72/14 and C-197/14, EU:C:2015:564.

53 Ferreira da Silva, cit., note 3, para 40; and $X$, cit., note 52, para 58.

$54 X$, cit., note 52, para 59.

55 Ibid, para 60-61.

56 Ferreira da Silva, cit., note 3, para 41-42. 
by conflicting lines of case-law within one Member State. Underlying the situation in the $X$ case and this explanation given in the Ferreira da Silva ruling are situations where the jurisprudential differences take place between lower national courts and the national supreme court of a specific Member State. The deference approach flows from the role of national supreme courts to resolve conflicts between decisions within their own jurisdiction. But, in situations where the jurisprudential differences take place among national courts wtihin the Union, the ECJ emphasised in Ferreira da Silva the role of national supreme courts as European courts.

Indeed, very different are situations characterised both by conflicting lines of case-law at the national level and difficulties of interpretation in the various Member States, since it is very difficult to challenge the existence of a reasonable doubt in a broader European context - and that was precisely the case in Ferreira da Silva. A fact ignored by the Supremo Tribunal de Justiça, the interpretation of the concept of 'transfer of a business' within the meaning of the Directive 2001/23 still raised questions to national courts which, in return, asked for preliminary rulings to the ECJ. Moreover, as the Advocate General pointed out in its Opinion, the concept of 'transfer of a business' is based on a case-by-case analysis; therefore, the ECJ's case-law relevant for the interpretation of this concept, triggered by questions raised by national courts, is in permanent evolution ${ }^{57}$. Hence, neither was the previous case-law sufficiently enlightening, nor was the matter as equally obvious to the courts of other Member States and to the ECJ as it had been for the Supremo Tribunal de Justiça - in other words, the requirements attached to both the prior ECJ ruling and the acte clair criteria were not met.

These difficulties of interpretation and the risk of diverse readings within the Union were thus not sufficiently acknowledged by the Supremo Tribunal de Justiça. Therefore, the ECJ, in a very clear and straightforward fashion, concluded that in circumstances characterised both by (i) conflicting lines of case-law at national level concerning the concept of 'transfer of a business' within the meaning of the Directive 2001/23 and by (ii) difficulties of interpretation of that same concept in various Member States, a national court against whose decisions there is no judicial remedy under national law, such as the Supremo Tribunal de Justiça, «is obliged to make a reference to the Court for a preliminary ruling concerning the interpretation of that concept ${ }^{58}$. The

57 Opinion of Advocate General Bot in Ferreira da Silva, cit., note 34, para 97-100.

58 Ferreira da Silva, cit., note 3, para 43-45. 
Ferreira da Silva ruling was the first ruling ${ }^{59}$ in which the ECJ concluded that a national court adjudicating at last instance had failed to comply with its obligation to make a reference for a preliminary ruling under Article 267(3) TFEU.

It is also to be recalled that the Supremo Tribunal de Justiça had considered that some of the questions raised by the applicants in the Ferreira da Silva proceedings could not be assessed by the ECJ for lack of jurisdiction, since the questions concerned the compatibility of Portuguese law with the Directive 2001/23. However, this was not - and could not have been - the main reason to justify the absence of a reference for a preliminary ruling. Many questions brought before the ECJ are, precisely, linked to hypothetical compatibility, or lack of thereof, between national law and EU law - that is the main concern of national courts. This does not prevent the ECJ from providing a useful answer. Considering the spirit of cooperation that characterises the preliminary ruling mechanism, the ECJ usually rephrases the question by identifying the question of interpretation of EU law at stake, in order to provide the referring court with the relevant elements enabling it to subsequently assess the compatibility of national law with EU law.

\section{FERREIRA DA SILVA IN LIGHT OF KÖBLER - ITS IMPLICATIONS ON THE STATE LIABILITY REGIME IN CASE OF BREACH OF EU LAW BY A NATIONAL COURT ADJUDICATING AT LAST INSTANCE}

The failure by a court adjudicating at last instance to comply with its obligation to make a reference for a preliminary ruling under Article 267(3) TFEU triggers several consequences. In his Opinion regarding the Traghetti del Mediterraneo case, Philippe Léger pointed out that the failure to comply with that obligation is likely to lead the concerned court to commit either an error in the interpretation of the EU law applicable, or an error regarding the consequences to be drawn from that law in order to ensure a consistent interpretation of national law or to assess whether that law is compatible with EU law ${ }^{60}$. Yves Bot, in his Opinion in the Ferreira da Silva case, added that, in these circumstances, the ECJ is deprived of ensuring that «in the interpretation and application of the Treaties the law is observed» [Article 19(1) TEU] ${ }^{61}$.

\footnotetext{
59 But no longer the only one - see Judgment of the Court in Doc Generici, C-452/14, EU:C:2015:644, para 42-45.

60 Opinion of Advocate General Léger in Traghetti del Mediterraneo, C-173/03, EU:C:2005:602, para 66.

61 Opinion of Advocate General Bot in Ferreira da Silva, cit., note 34, para 102.
} 
More importantly, in the Köbler ruling, the ECJ recognised that the absence of a reference for a preliminary ruling, whenever it is mandatory under Article 267(3) TFEU, leads to the frustration of claims aimed at the effective judicial protection of the rights granted by EU law to individuals. Therefore, Köbler enshrines the acknowledgement of a subjective dimension within the preliminary ruling mechanism. Although mainly design to ensure the proper and uniform interpretation and application of EU law, it is also a mechanism serving the effective judicial protection of rights which EU law confers on individuals since the failure to comply with the obligation under Article 267(3) TFEU may lead to compensation for the injured individuals.

The conditions for State liability for breaches of EU law have been well known ${ }^{62}$ since the rulings on Francovich and Brasserie du Pêcheur: (i) the rule of law infringed must have been intended to confer rights on individuals, (ii) the breach must be sufficiently serious and (iii) there must be a direct causal link between the breach of the obligation resting on the State and the damage sustained by the injured parties ${ }^{63}$. The cumulative existence of these conditions is enough to trigger a right to compensation for damages founded «directly» ${ }^{64}$ on EU law and the "inherent principles»" ${ }^{65}$ of the EU legal order, namely the principle of effectiveness of EU rules and the effective judicial protection of the rights granted by EU law to individuals and the principle of loyal cooperation [Article 4(3) TEU] ${ }^{66}$. The assessment of these conditions lies within the competence of the national court that shall, however, consider the observations of the ECJ regarding the interpretation

62 Although not entirely unproblematic, whether the breach of EU law at stake is attributable to the judiciary or not — see, for instance, Georgios ANAGNOSTARAS, "Not as unproblematic as you might think: the establishment of causation in governamental liability actions», ELRev, no. 27, 2002, pp. 663-676, and Björn BEUTLER, «State liability for breaches of Community law by national courts: is the requirement of a manifest infringement of the applicable law an insurmountable obstacle?», CMLRev, no. 46, 2009, pp. 773-804.

Judgment of the Court in Dillenkofer, C-178/94, C-179/94, C-188/94, C-189/94 and C-190/94, EU:C:1996:375, para 20-27 and para 21 in particular, in which the ECJ stabilized the formulation of the constitutive conditions of Member State liability for breaches of EU law resulting from earlier case-law, namely Francovich, cit., note 19, para 38-40, and Judgment of the Court in Brasserie du Pêcheur, C-46/93 and C-48/93, EU:C:1996:79, para 51.

64 Francovich, cit., note 20, para 41.

65 Brasserie du Pêcheur, cit., note 63, para 39.

66 Francovich, cit., note 20, para 31-36 and 45, and Brasserie du Pêcheur, cit., note 63, para 31 and 39. 
of each condition ${ }^{67}$, either considering its general case-law or a specific judgment delivered after a reference for a preliminary ruling is made in the liability proceedings.

In the Köbler ruling that case-law was applied for the first time to a situation of breach of EU law attributable to a court adjudicating at last instance ${ }^{68}$. As the ECJ recalled in Ferreira da Silva, «in view of the essential role played by the judiciary in the protection of the rights derived by individuals from the rules of EU law, the full effectiveness of those rules would be called in question and the protection of those rights would be weakened if individuals were precluded from being able, under certain conditions, to obtain reparation when their rights are prejudiced by an infringement of EU law attributable to a decision of a court or tribunal of a Member State adjudicating at last instance ${ }^{69}$. Regard to the specific nature of the judicial function, as well as the legitimate requirements of legal certainty, motivated the finding that State liability for a breach of EU law by a decision of a national court adjudicating at last instance can be incurred "only in the exceptional case where the court has manifestly infringed the applicable law» ${ }^{70}$. Moreover, and here lies the key point of the Köbler ruling, the non-compliance with the obligation of a national court to refer to the ECJ under Article 267(3) TFEU added up to the list of elements to consider when assessing the sufficiently serious breach of EU law as a condition to establish State liability ${ }^{71}$.

At the end, the ECJ considered that the breach attributable to the Landesgericht für Zivilrechtssachen Wien in the Köbler case was not sufficiently serious as it was based in a misreading of one previous ruling ${ }^{72}$. However, in the same way now in Ferreira da Silva, the ECJ had also held in Köbler that the national court was not entitled to take the view that the resolution of the point of law at issue was clear from settled case-law or left no room for any reasonable doubt ${ }^{73}$. In both cases, the points of EU law at issue were respectively settled in the Köbler and the Ferreira da Silva rulings delivered by the ECJ while the liability proceedings were pending. Where, then, would the difference lie between the Landesgericht für Zivilrechtssachen Wien whose breach of EU law was not characterised as being manifest in nature and thus

\footnotetext{
67 Brasserie du Pêcheur, cit., note 63, para 55-58.

68 Köbler, cit., note 22, para 30-50, and case-law cited.

69 Ferreira da Silva, cit., note 3, para 47, and Köbler, cit., note 22, para 33.

70 Köbler, cit., note 22, para 53.

71 Ibid, para 55-56.

72 Ibid, para 120-124.

73 Ibid, para 118.
} 
as sufficiently serious to engage State liability ${ }^{74}$, and the Supremo Tribunal de Justiça whose breach of EU law ought to be considered as such, when in both cases said breach is the same (the infringement of the obligation to make a reference for a preliminary ruling under Article 267(3) TFEU without the conditions laid down in Cilfit being met)?

In the Köbler case, having initially made a reference for a preliminary ruling but then withdrawing its request and deciding based on an incorrect reading of a ruling in the meantime delivered by the $\mathrm{ECJ}^{75}$, the Landesgericht für Zivilrechtssachen Wien showed no intention of evading its obligations as a judge of the Union; consequently, its withdrawal, although contrary to Article 267(3) TFEU, did not manifestly infringed the applicable law and thus was not considered as sufficiently serious. In other words, the error of law was excusable under the Brasserie du Pêcheur ruling ${ }^{76}$. That was not the case, however, in the Ferreira da Silva case. The ECJ concluded, clearly and forcefully, that the Supremo Tribunal de Justiça was required to make a reference for a preliminary ruling. By not doing so, and without the conditions laid down in Cilfit being met, the Portuguese court adjudicating at last instance had failed to comply with its obligation which the Treaty imposed, in those specific circumstances, in a «clearly defined way» within the meaning of the Van Gend \& Loos ruling mentioned above ${ }^{77}$. When deciding not to make a reference for a preliminary ruling with no considered certainty and without internalizing in its decision the consequences it might have in a larger EU context, the Supremo Tribunal de Justiça manifestly ignored the applicable law as determined by the Köbler ruling ${ }^{78}$.

In other words, in concluding that the Supremo Tribunal de Justiça was under the obligation to make a reference for a preliminary ruling and that it failed to do so, the Ferreira da Silva judgment also implies that the Supremo Tribunal de Justiça manifestly infringed EU law within the meaning of the ECJ's settled case-law on the concept of «sufficiently serious breach of EU law», especially within the meaning developed in Köbler. This reasoning shall be considered by the Varas Civeis de Lisboa where the liability proceedings are pending, along with the other conditions for State liability. And, if those conditions are equally met, it follows from the Ferreira da Silva ruling, read in the light of the Van Gend \& Loos and the Köbler case-law, that from the failure

\footnotetext{
74 Ibid, para 124.

75 Ibid, para 123.

76 Brasserie du Pêcheur, cit., note 63, para 55.

77 Van Gend \& Loos, cit., note 13, p. 12.

78 Köbler, cit., note 22, para 53.
} 
to comply with the obligation to make a reference for a preliminary ruling, which is imposed in a "clearly defined way» in Article 267(3) TFEU upon national courts adjudicating at last instance, a subjective right to compensation arises for the injured individuals and becomes "part of their legal heritage» ${ }^{79}$. In this sense, the Ferreira da Silva ruling confirms the subjective dimension of the preliminary ruling mechanism, when mandatory, implied in Köbler. But the contributions of the Ferreira da Silva ruling on State liability for breaches of EU law attributable to a national court adjudicating at last instance do not stop here.

It follows from established case-law, also mentioned in Ferreira da Silva, that

[...] where the conditions for a State to incur liability are satisfied, a matter which it is for the national courts to determine, it is on the basis of the rules of national law concerning liability that the State must make reparation for the consequences of the loss or damage caused, provided that the conditions laid down by national law in respect of reparation of loss or damage are not less favourable than those relating to similar domestic claims (principle of equivalence) and are not so framed as to make it, in practice, impossible or excessively difficult to obtain reparation (principle of effectiveness $)^{80}$.

In the proceedings pending before the Varas Civeis de Lisboa, the Portuguese State shielded itself in the provision of Article 13(2) RRCEE in order to not be considered liable. Under this legal provision, any claim for compensation based on the liability of the State for damages caused in the exercise of the judicial function «must be based on the prior setting aside of the decision that caused the loss or damage by the court having jurisdiction ${ }^{81}$.

Under this requirement, the unlawfulness of the harmful judicial decision must be demonstrated, not in the liability proceedings intended to the actual exercice of the right to compensation, but in the very judicial proceedings leading to that decision through the judicial remedies that might, in each case, be admissible. Thus, the absence of revocation of the harmful judicial decision determines, by itself, the inadmissibility of any damages action. That is the reason why, in the Ferreira da Silva case, the Portuguese State submitted that the damages sought by the applicants

79 Van Gend \& Loos, cit., note 13, p. 12.

80 Ferreira da Silva, cit., note 3, para 50.

81 Ibid, para 7. 
were not payable for the decision of the Supremo Tribunal de Justiça had not been set aside ${ }^{82}$.

Before the ECJ, it was confirmed in the different phases of the Ferreira da Silva proceedings that the situations in which decisions of the Supremo Tribunal de Justiça may be subject to appeal are extremely limited. Those decisions may only be set aside through a request for reform of sentencing or under the limited conditions governing the extraordinary appeal for revision ${ }^{83}$. The first hypothesis does not provide sufficient guarantees of impartiality as the request is made to the court that issued the sentence, in casu the Supremo Tribunal de Justiça itself. As for the second hypothesis, the only relevant ground for revision would be that the final decision is «irreconcilable with a final decision of an international instance of binding appeal for the Portuguese State». Even if one interprets this expression as covering the ECJ, the matter is that individuals do not have access to any procedure that would lead to a decision from the ECJ that could substantiate the request for revision. The Portuguese academic literature has widely pointed out the failure of this mechanism to ensure the full effect of EU law ${ }^{84}$. The ECJ upheld the assertion in respect of the infringement of the obligation to make a reference for a preliminary ruling under Article 267(3) TFEU. The application of a provision such as Article 13(2) RRCEE has, as a consequence, that «any action for damages against the State for infringement of the obligation stemming from the failure to comply with the duty imposed by the third paragraph of Article 267 TFEU will be inadmissible if the decision that caused the loss or damage has not been set aside» ${ }^{85}$. It was therefore not particularly difficult for the ECJ to consider the provision of Article 13(2) RRCEE contrary to the principle of effectiveness as it makes it extremely difficult to obtain reparation ${ }^{86}$.

82 Ibid, para 20.

83 See Articles 619. (reforma da sentença) and 696. (recurso extraordinário de revisão) of the Portuguese Code of Civil Procedure approved by the Law no. 41/2013 of 26 June, corresponding to Articles $669 .^{\circ}$ and $771 .^{\circ}$ of the now revoked 1961 Code.

84 See Maria José RANGEL DE MESQUITA, O Regime da Responsabilidade Civil Extracontratual do Estado e demais Entidades Públicas e o Direito da União Europeia [The Regime of Non-contractual Civil Liability of the State and other public bodies and European Union Law], Almedina, Coimbra, 2009, pp. 55-56; PEREIRA COUTINHO, op. cit., note 46, p. 284; João RAMOS LOPES, «A question of procedural law: the principle of the inalterable nature of a tried case and the violation of EU law», Unio, no. 0 (inaugural edition), 2014, pp. 101-112, available at http:// www.unio.cedu.direito.uminho.pt (last accessed on 28.6.2016). Ferreira da Silva, cit., note 3, para 49.

Ibid, para 51-59. 
Moreover, the ECJ held that the obstacle set out by Article 13(2) RRCEE could not be justified by other general principles of EU law, such as the principle of res judicata or legal certainty. The Köbler ruling had already established that the principle of State liability for a decision of a national court adjudicating at last instance contrary to EU law does not in itself have the consequence of invalidating the status of res judicata of the judicial decision which was responsible for the damage as it only requires reparation, not the revision of the judicial decision at stake ${ }^{87}$. As far as the principle of legal certainty goes, to consider it here could preclude individuals from invoking the rights granted by EU law, especially the right to compensation that emerges from State liability for breaches of EU law. None of these two principles could compromise a "principle as fundamental as that of State liability for infringement of EU law» which is «inherent in the system of the Treaties on which the European Union is based ${ }^{88}$. Once more, the ECJ's answer is clear and straightforward:

EU law and, in particular, the principles laid down by the Court with regard to State liability for loss or damage caused to individuals as a result of an infringement of EU law by a court or tribunal against whose decisions there is no judicial remedy under national law must be interpreted as precluding a provision of national law which requires, as a precondition, the setting aside of the decision given by that court or tribunal which caused the loss or damage, when such setting aside is, in practice, impossible ${ }^{89}$.

Consequently, the provision of Article 13(2) RRCEE is not to be applied in the proceedings pending before the Varas Civeis de Lisboa, nor by any other Portuguese court, nor by any other national court faced with a provision of domestic law similar to Article 13(2) RRCEE both in its content and/or its consequences. As was pointed out by Daniel Sarmiento, in the Ferreira da Silva ruling the ECJ not only challenged a national supreme court for the way in which it had handled EU law and its obligation to make a reference for a preliminary ruling, but also «removed another brick in the wall that protects national courts from intrusive (but sometimes rightful) litigants invoking EU

87 Köbler, cit., note 22, para 39.

88 Ferreira da Silva, cit., note 3, para 58-59.

89 Ibid, para 60. 
Law» ${ }^{90}$. Just as it did in the Traghetti del Mediterraneo case ${ }^{91}$, the ECJ ruled out one national provision applicable to State liability for a breach of EU law proceddings whose main goal is to leave national courts adjudicating at last instance free from any damages actions and whose practical consequences are to leave injured parties unprotected and (sufficiently serious) breaches of EU law unharmed.

The conclusion reached in Ferreira da Silva concerning Article 13(2) RRCEE may seem a rather obvious one. The Ferreira da Silva judgment does not, in itself, reveal anything that would not logically flow from previous caselaw. It is not the case, however, if one considers that, within the Portuguese specific context, the reference for a preliminary ruling that occasioned the Ferreira da Silva judgment was more overdue than premature. Within the context of the approval of the RRCEE, the Portuguese doctrine had already highlighted the fact that State liability for damages caused in the exercise of the judicial function existed irrespective of the revision or the withdrawal of the harmful judicial decision when at stake was a breach of EU law ${ }^{92}$. Additionally, while the procedure in the Ferreira da Silva case was pending before the ECJ, both the Portuguese Supremo Tribunal de Justiça and Tribunal Constitucional (Constitutional Court) declared the provision of Article 13(2) RRCEE as not unconstitutional. In both decisions, the legal certainty associated with final judicial decisions and the authority of the decisions of the higher courts, attached to the hierarchical structure of the judicial system, were considered

90 Daniel SARMIENTO, «Final courts' obligations to refer questions: the CJEU clarifies CILFIT», EU Law Analysis, http://eulawanalysis.blogspot.pt/2015/09/final-courtsobligations-to-refer.html (last accessed on 28.6.2016).

91 Traghetti del Mediterraneo, cit., note 33, para 46.

92 Alessandra SILVEIRA, «Da (ir)responsabilidade do Estado-juiz por violação do Direito da União Europeia. Anotação ao Acórdão do Supremo Tribunal de Justiça de 3 de Dezembro de 2009" [About the (ir) responsibility of the judiciary State for breaches of EU law. Annotation to the Judgment of the Supreme Court of Justice of 3 December 2009], Scientia Iuridica, no. 320, 2009, pp. 773-804; Maria José RANGEL DE MESQUITA, «Irresponsabilidade do Estado-Juiz por incumprimento do Direito da União Europeia: um acórdão sem futuro. Anotação ao Acórdão do STJ (1. a Secção) de 13 de dezembro de 2009" [The irresponsibility of the judiciary State for breaches of EU law: a judgment without a future. Annotation to the Judgment of the STJ ( $1^{\text {st }}$ Chamber) of 13 December 2009], Cadernos de Justiça Administrativa, no. 79, 2010, pp. 29-45; and Carla AMADO GOMES, «ABC da (in)responsabilidade dos juízes no quadro da Lei n. ${ }^{\circ}$ 67/2007, de 31 de Dezembro" [ABC of the irresponsability of the judges under the Law no. 67/2007 of 31 December], Scientia Iuridica, no. 322, 2010, pp. 261-277; PEREIRA COURTINHO, op. cit., note 46, pp. 283-284. 
to be especially inherent to the legislative option shaped in Article 13(2) RRCEE. In a decision of the 24 February 2015, the Supremo Tribunal de Justiça emphasised that the solution adopted aims to harmonize the State liability institute with the principle of res judicata and legal certainty, not excluding nor limiting arbitrarily or disproportionately the principle of State liability, and the inherent right to compensation, enshrined in Article 22 of the Portuguese Constitution ${ }^{93}$. In turn, for the Tribunal Constitucional, as expressed in its judgment of 9 July 2015, the provision of Article 13(2) RRCEE does not eliminate the right to compensation, but only accommodates the regime of State liabily for damages caused in the exercise of the judicial function to the requirements related the structure and functioning of the judicial system constitutionally guaranteed and does not disregard the essential content of the Portuguese constitutional law ${ }^{94}$.

In its decision, the Tribunal Constitucional acknowledged the incompatibility of Article 13(2) RRCEE with EU law and, in particular, with the principles laid down in the Köbler ruling ${ }^{95}$. Thus, a double standard remains applicable depending on the State liability being founded in a violation of EU law or not. As a result - of questionable legitimacy under the principle of equality - the Portuguese State only incurs liability for loss or damages caused by a judicial decision, without the setting aside of the harmful judicial decision being required, when the action is founded on EU law - which encourages litigants to establish even tenuous connections with EU law. So, if one may argue that the ruling on Ferreira da Silva is not surprising, it nevertheless contributes to make the Portuguese legal regime on the State liability for damages caused in the exercise of the judicial function compliant with the ECJ's case-law on the matter. As it can be inferred from the proceedings pending in the Varas Civeis de Lisboa, the question was not as blunt as it might have seemed $^{96}$. This leads us to the next question.

93 See Judgment of the STJ of 24.2.2015, case 2210/12.9TVLSB.L1.S1, part IV, para 3 to 6, available at www.dgsi.pt (last accessed on 28.6.2016).

94 See Judgment of the TC no. 363/2015 of 9.7.2015, case 185/15, para 10-13, available at http://www.tribunalconstitucional.pt (last accessed on 28.6.2016).

95 Ibid, para 11.

96 The provision of Article 13(2) RRCEE is not the only provision of RRCEE whose compatibility with EU law is called into question by the Portuguese academic literature - in this sense, see RANGEL DE MESQUITA, op. cit., note 84; and Sophie PEREZ FERNANDES, A Responsabilidade do Estado-Legislador por Violação do Direito da Uniāo Europeia. Breves Notas sobre o Caso Português [The Responsibility of the Legislator State for breaches of EU law. Brief notes on the Portuguese Case], Principia, Cascais, 2013. 


\section{WHAT IF THE FERREIRA DA SILVA JUDGMENT HAD NOT BEEN DELIVERED? THE SANTOS PARDAL JUDICIAL SAGA}

Throughout the integration process, individuals played an active role as guardians of the integrity of the Union's legal order ${ }^{97}$. The perseverance of the applicants in the Ferreira da Silva case is an excellent example of this. Had the Varas Civeis de Lisboa refrained from requesting a preliminary ruling, they would have assessed alone, without the ECJ's assistance, the compliance by the Supremo Tribunal de Justiça of its obligation to make a reference for a preliminary ruling under Article 267(3) TFEU and the possible application of Article 13(2) RRCEE to these proceedings, with risks for the proper application of EU law and for the guarantee of the effective judicial protection of the applicants' rights in the main proceedings. Unfortunately, other proceedings that also took place before Portuguese courts demonstrate that this question is not merely hypothetical. The proceedings in Santos Pardal, which in the end led to a decision of the ECtHR, allow us to speculate what might have happened had the Varas Civeis de Lisboa refrained from making a reference for a preliminary ruling or, in other words, if the «vigilance of individuals concerned to protect their rights» had been faced with the unwillingness of the competent national courts and, in particular, of the court adjudicating at last instance, to make a reference for a preliminary ruling to the ECJ under Article 267 TFEU.

In 1997, José Luís Ferreira Santos Pardal was injured in a car accident; he followed as a passenger in the vehicle he owned at the time of the accident. In the liability action brought against the insurance company, the compatibility with the Directive 90/232 $2^{98}$ of the Portuguese transposition instrument was questioned. The national courts that assessed the compensation request, including the Supremo Tribunal de Justiça, did not accept the applicant's request considering that the national provisions did not cover physical damages of the owner of the vehicle (and insurance holder) when, at the time of the accident, he was the passenger and not the driver. Santos Pardal suggested before the three judicial instances that assessed his claim that a reference for a preliminary ruling should be made to the ECJ regarding the interpretation of Article 1 of the Directive 90/232, particularly on the question of whether

97 J.H.H. WEILER, The Constitution of Europe. 'Do the New Clothes Have an Emperor?' and Other Essays on European Integration, Cambridge University Press, 1999, p. 20.

98 Third Council Directive 90/232/EEC of 14 May 1990 on the approximation of the laws of the Member States relating to insurance against civil liability in respect of the use of motor vehicles (OJ L 129, 19.5.1990, pp. 33-35). 
the compulsory insurance against civil liability in respect of the use of motor vehicles covered or not the damage sustained by the vehicle owner and insurance holder who followed as a passenger in his own vehicle at the time of the accident. None of the judicial instances, not even the Supremo Tribunal de Justiça adjudicating at last instance by judgment of the 14 December 2004 ${ }^{99}$, made a reference for a preliminary ruling.

However, when the Supremo Tribunal de Justiça delivered its judgment, some proceedings had already been brought before the ECJ concerning a similar question, which revealed the existence of a reasonable doubt of interpretation within the meaning of the Cilfit case-law. Moreover, a year later, those proceedings resulted in the Katja Candolin ruling ${ }^{100}$ in which the ECJ sustained an interpretation favourable to the claim made by Santos Pardal ${ }^{101}$, interpretation later confirmed in the Elaine Farrel ruling ${ }^{102}$ and that the Supremo Tribunal de Justiça itself would also follow ${ }^{103}$. In face of such developments, similarly to the applicants in Ferreira da Silva, Santos Pardal brought an action against the Portuguese State for breaches of EU law arguing that, in its judgment in 2004, the Supremo Tribunal de Justiça (i) had erroneously interpreted the Directive 90/232/CEE and (ii) had failed to comply with its obligation to make a reference for a preliminary ruling under Article 267(3) TFEU.

Another judicial round began which, unfortunately, did not result in the same outcome as in Ferreira da Silva. The Tribunal Judicial de Braga (Judicial Court of Braga) dismissed the liability action but, later, the Tribunal da Relação de Guimarães (Court of Appeal of Guimarães) partially granted the request, condemning the Portuguese State in the payment of compensation ${ }^{104}$. It happens that, in a judgment of 3 December 2009, the Supremo Tribunal de Justiça revoked the decision of the Tribunal da Relação de Guimarães. The Supremo Tribunal de Justiça sustained that the non-contractual liability of the State regime in force at the time of the facts did not entail the liability for damages caused in the exercise of the judicial function. Accordingly, it only made sense to make the State liable for damages in the exercise of the judicial function from the entry into force of the RRCEE in 2007 onwards, but

\footnotetext{
99 Judgment of the STJ of 14.12.2004, case 541/2000, not published.

100 Judgment of the Court in Katja Candolin, C-537/03, EU:C:2005:417.

101 Ibid, para 27.

102 Judgment of the Court in Elaine Farrell, C-356/05, EU:C:2007:229.

103 Judgments of the STJ of 16.1.2007, Case 06A2892, and of 22.4.2008, case 08B742, both available at www.dgsi.pt (last accessed on 4.5.2016).

104 A decision welcomed by the Portuguese doctrine - see SILVEIRA, op. cit., note 92, p. 787, and RANGEL DE MESQUITA, op. cit., note 92, p. 40.
} 
«always within the tight limits of Article 13, and never before, i.e., based on the revoked Decreto-Lei no. 48 051, of 21 November 1967» ${ }^{105}$. The Supremo Tribunal de Justiça thus considered the RRCEE in force since 2007 and its Article 13(2) specifically the beginning and the end of State liability for damages caused in the exercise of the judicial function, bluntly ignoring the ECJ's case-law on State liability for breaches of EU law. It goes without saying that, despite the applicant's suggestion for a reference for a preliminary ruling to be made, the Supremo Tribunal de Justiça also dismissed this request.

The domestic remedies being exhausted, and without the ECJ having had the chance to provide a preliminary ruling, Santos Pardal initiated a third judicial round, this time before the ECtHR, claiming to have been deprived of his right to a fair trial under Article 6 of the European Convention on $\mathrm{Hu}$ man Rights (ECHR) ${ }^{106}$. In a judgment of the 30 July $2015^{107}$, the ECtHR found a violation of Article 6 ECHR verified due to an internal jurisprudential divergence regarding the admissibility of liability actions brought against the State for damages caused in the exercise of the judicial function. Indeed, in its judgment of 3 December 2009, the Supremo Tribunal de Justiça decided contrarily to national case-law that recognised the liability of the State for damages caused in the exercise of the judicial function, either based on the decree revoked by the RRCEE or in the direct application of Article 22 of the Portuguese Constitution. According to the ECtHR, the Supremo Tribunal de Justiça, as a court adjudicating at last instance, had created a situation of jurisprudential uncertainty likely to infringe the principle of legal certainty. This uncertainty led to the dismissal of the action brought by Santos Pardal and deprived him from the possibility of seeing his claim for compensation against the State analysed, while other applicants in similar conditions saw that right recognised.

105 Judgment of the STJ of 3.12.2009, case 9180/07.3TBBRG.G1.S1, para 1 of the summary, available at www.dgsi.pt (last accessed on 28.6.2016) (translation of the Authors).

106 The ECtHR had previously declared inadmissible under Article 35(4) ECHR the part of the application fouded in the infringement of the obligation to make a reference for a preliminary ruling under Article 267(3) TFEU. The ECtHR merely considered that, in its judgment of the 14 December 2004, the Supremo Tribunal de Justiça had, for the purposes of Article 6(1) ECHR, sufficiently motivated its decision not to refer to the ECJ for the interpretation of the Directive 90/232/CEE did not raise any doubts in light of the national jurisprudence existing at the time - see Ferreira Santos Pardal v. Portugal (dec.), 4 September 2012, no. 30123/10.

107 Ferreira Santos Pardal v. Portugal, 30 July 2015, no. 30123/10, para 48-51. 
The ruling of the ECtHR on the Santos Pardal case recognises a violation of Article $6 \mathrm{ECHR}$, in what concerns the principle of legal certainty, due to the Portuguese jurisprudential divergence - and, in particular, within the Supremo Tribunal de Justiça jurisprudence — regarding the admissibility of liability actions brought against the State for damages caused in the exercise of the judicial function. This divergence assumes even more serious contours if one considers the ECJ's case-law on the matter: the decision of the Supremo Tribunal de Justiça of 3 December 2009, by denying the liability of the State for damages caused in the exercise of the judicial function, collides with established case-law of the ECJ on the matter.

Therefore, had the Supremo Tribunal de Justiça completely and fully considered the ECJ's relevant case-law, it would not have disregarded the State liability for damages caused in the exercise of the judicial function, since the principle of State liability for breaches of EU law applies over any internal legal provision contrary to EU law (principle of primacy). In this sense, it was actually irrelevant whether national courts recognised or not the principle of State liability for damages caused in the exercise of the judicial function based on the former regime (previous to the RRCEE) or in the Article 22 of the Portuguese Constitution as, in what concerns EU law, this liability emerges from a fundamental principle inherent in the system of the Treaties on which the Union is based.

Another problem that could occur in the Ferreira da Silva case - and whose risk is not completely assuaged - relates to the fact that the Supremo Tribunal de Justiça, on appeal, may come to be the judge of the liabity action based on the harmful decision it made. So it happened in the Santos Pardal case: in its judgment of 3 December 2009, the Supremo Tribunal de Justiça ruled on a liability claim founded on its own judgment dated 14 December 2004. Thus, before the ECtHR, the applicant also complained of a lack of impartiality of the Supremo Tribunal de Justiça on the grounds that it was asked to rule on a legal error which it originally made. However, given its previous finding of violation on Article 6(1) ECHR for differing interpretations by the Supremo Tribunal de Justiça, the ECtHR considered that there was no need to examine whether there had also been a violation of the same provision for lack of impartiality of the same Supremo Tribunal de Justiça ${ }^{108}$. Thus, the issue was not assessed by the ECtHR.

The right of every person to have his or her case heard by an independent and impartial tribunal is one aspect of the broader right to a fair trial guaranteed by both Article 6 ECHR and Article 47 CFREU. Accordingly, both the

108 Ibid, para 52-55. 
$\mathrm{ECtHR}^{109}$ and the ECJ ${ }^{110}$ assess the impartiality of a court or tribunal based on a double test: the subjective test aims at ascertaining the personal conviction of a given judge in a given case (the judge must show no bias or personal prejudice) and the objective test, which aims at ascertaining whether there are sufficient guarantees to exclude any legitimate doubt in this respect. As the ECtHR has pointed out, those requirements, as features of the wider concept of a fair trial, are justified by "the importance attached to appearances and to the increased sensitivity of the public to the fair administration of justice» ${ }^{111}$.

Now, if the purpose of those provisions is to prevent the delivery of biased decisions, the possibility of the same court to hear and adjudicate the liability action brought against the State based on a decision by itself previously issued creates (at least) doubts about their objective impartiality. As Philippe Léger had previously warned, «it is not feasible to entrust a judicial body with the task of determining whether its own conduct is wrongful or unlawful», as that "would unquestionably be contrary to the principle of an impartial tribunal laid down in Article 6(1) of the Convention» ${ }^{12}$. In the Köbler case, the same Advocate General also questioned the impartiality of national courts which would have to hear and adjudicate on actions for damages against the State as a result of a decision of a supreme court in the light of the requirements imposed by Article 6(1) ECHR ${ }^{113}$. This is, a fortiori, the case when a supreme court is to hear and adjudicate actions for damages against the State as a result of a decision it has previously issued. The hypothesis had also been considered by Philippe Léger: "The example of a court which has to decide whether its own functioning was illegal or wrongful in order to determine an action for compensation, even if its constitution is altered so that the judges who gave the original judgment are not the same as those who have to

109 See, to that effect, inter alia, Piersack v. Belgium, 1 October 1982, no. 8692/79, para 30; Fey v. Austria, 24 February 1993, no. 14396/88, para 28; Findlay v. United Kingdom, 25 February 1997, no. 22107/93, para 73; and Forum Maritime S.A.v. Roumanie, 4 October 2007, nos. 63610/00 and 38692/05, para 116. The last three judgments were expressely considered by the ECJ in its judgments mentioned in the following footnote.

110 See, to that effect, in particular, Judgments of the Court in Chronopost SA and La Poste, C-341/06 P and C-342/06 P, EU:C:2008:375, para 54, and in Koldo Gorostiaga Atxalandabaso, C-308/07 P, EU:C:2009:103, para 46.

111 Borgers v. Belgium, 30 October 1991, no. 12005/86, para 24.

112 Opinion of Advocate General Léger in Baustahlgewebe, C-185/95 P, EU:C:1998:37, para 67.

113 See Opinion of Advocate General Léger in Köbler, C-224/01, EU:C:2003:207, para 107. 
assess the court's own liability, seems to me a perfect illustration of a breach of the principle of impartiality» ${ }^{114}$.

In the Köbler case the issue was raised, but under the principle of procedural autonomy, the ECJ did not intervene in solving these problems of competence ${ }^{115}$. Several solutions may be advanced to circumvent the problem: the liability action brought against the State based on a decision issued by a supreme court could be heard and decided by a special court, by an extended section of the same supreme court composed of different judges than those who issued the decision at the origin of the damages claim ${ }^{116}$, or by a supreme court of another jurisdiction (if one exists in the national judicial system). These solutions entail, however, the risk of giving rise to new liability actions ${ }^{117}$. With respect for other opinions, and specifically regarding the State liability for damages caused in the exercise of the judicial function founded in breaches of EU law, the solution proposed by Philipe Léger, resorting to the preliminary ruling mechanism, seems to us the most appropriate:

[...] a guarantee of impartiality could be identified in the mechanism of judicial cooperation provided by the preliminary ruling procedure. Indeed, in order to dispel any reasonable doubt as to its impartiality, the national court might choose to refer a question for a preliminary ruling and thus entrust to the Court the responsibility of examining whether the supreme court concerned has in fact acted in breach of Community law and, if so, to what extent. Recourse to such a procedure would offer a dual advantage since it would make it possible both to dispel any reasonable doubt as to the impartiality of the national court and to give guidance to that court in this delicate exercise by avoiding the risk of error in the appraisal of an alleged error $^{118}$.

This solution further highlights the necessary judicial cooperation founded on the logic of dialogue and mutual trust between courts that is already institutionalised through the preliminary ruling mechanism. Unfortunately, in the Santos Pardal case, refraining from referring in its decision of

114 Opinion of Advocate General Léger in Baustahlgewebe, cit., note 112, note 34.

115 Köbler, cit., note 22, para 44-47.

116 Nuno PIÇARRA, «As incidências do direito da União Europeia sobre a organização e o exercício da função jurisdicional nos Estados-Membros» [The impact of EU law on the organization and the exercise of the judicial function in the Member States], Revista de Direito Público da Universidade do Porto, 2010, p. 222.

117 PEREIRA COUTINHO, op. cit., note 46, p. 287.

118 Opinion of Advocate General Léger in Köbler, cit., note 113, para 111. 
3 December 2009, the Supremo Tribunal de Justiça further deprived the ECJ of this opportunity of dialogue that would have been beneficial in a broader European context, but also deprived the litigant of sufficient guarantees of impartiality enshrined in his fundamental right to a fair trial guaranteed by both Article 6 ECHR and Article 47 CFREU. Let us hope that, if it comes to this in the Ferreira da Silva case, the Supremo Tribunal de Justiça will not follow its own footsteps.

\section{FINAL REMARKS}

In the Santos Pardal case, the vigilance of an individual concerned to protect his rights met with the systematic unwillingness of the national court adjudicating at last instance to make a reference for a preliminary ruling under Article 267(3) TFEU. Had the Varas Civeis de Lisboa refrained from referring to the ECJ in the proceedings that occasioned the Ferreira da Silva judgment, it is plausible to suppose that the situation in Santos Pardal would have happened again, especially if, as mentioned before, the Supremo Tribunal de Justiça kept insisting in considering the RRCEE, specifically its Article 13(2), the "alpha and omega» of the applicable law in State liability actions based on breaches of EU law attributable to a decision it made.

The case study presented here illustrates the necessary interaction between legal orders and their respective jurisdictions for the treatment of material dimensions that affect all. The full effectiveness of EU law and the protection of the rights it grants to individuals are seriously weakened when national courts take on a position of isolation ${ }^{119}$ when addressing issues that fall within the scope of application of EU law, isolation that annihilates any guarantee of uniform application of EU law, breaks with the idea of the Union as a Union based on the rule of law, runs over the principle of equality of individuals before the law, and especially prevents individuals from enjoying the standard of protection of their rights applicable to their specific situation.

In particular, the combined reading of both the Ferreira da Silva and the Santos Pardal cases highlights the serious consequences in terms of effective judicial protection that result from the infringement of the obligation to make a reference for a preliminary ruling under Article 267(3) TFEU. The preliminary ruling mechanism under Article 267 TFEU was not designed to

119 Thus concludes Francisco Pereira Coutinho its analysis on the degree of «Europeanisation» of the Portuguese courts - see PEREIRA COUTRINHO, op. cit., note 46, pp. 471-477. 
work as a remedy at the disposal of individuals who brought actions or initiated proceedings in a national court or tribunal based on or invoking EU law. The fact that the applicants consider that the proceedings raise questions of interpretation of EU law - and therefore require for a reference for a preliminary ruling to be made to the ECJ, eventually suggesting the questions to be submitted - does not bind the national court, even the court adjudicating at last instance, to actually refer, in the same way as the applicants' opposition does not prevent the judge's intention to do so by his own motto. It is within the exclusive competence of the judge, who is familiar with the proceedings and takes the sole responsibility for the judicial decision to be made, to determine in the light of the particular circumstances of the case both the need for a preliminary ruling from the ECJ in order to enable it to deliver judgment and the relevance of the questions to be submitted ${ }^{120}$.

However, this does not undermine the recognition of a subjective dimension entailed in this mechanism, especially when at stake is the obligation to make a reference for a preliminary ruling under Article 267(3) TFEU. The infringement of this obligation precludes individuals (even if indirectly) from obtaining a decision from the competent court because, if the reference for a preliminary ruling is mandatory, the ECJ is the competent court to assess the questions of interpretation of EU law raised — or, in the precise terms of Article 19(1) TEU, it is for the ECJ to «ensure that in the interpretation and application of the Treaties the law is observed». The same is true, all the more, when at stake is a preliminary ruling in light of the Foto-Frost case-law ${ }^{121}$.

But here is the catch. If the only judicial remedy available to individuals to react against the failure to comply with the obligation to make a reference for a preliminary ruling - which consists in bringing before the competent national courts an action of liability against the State for the breach of EU law attributable to the decision from the court adjudicating at last instance — fails, then EU law also fails in providing with an appropriate answer to the injured party. It was precisely what happened in the Santos Pardal case: the domestic remedies being exhausted, and in the inability to resort to the ECJ, the individual addressed the ECtHR. The Strasbourg Court was thus the only safe shelter for effective judicial protection as the competent court - the legal judge of European questions, i.e. the ECJ under Article 19(1) TEU — was deprived of the opportunity to assess the claim and was ultimately prevented

120 Judgment of the Court in Eon Aset Menidjmunt, C-118/11, EU:C:2012:97, para 76 and case-law cited.

121 Judgment of the Court in Foto-Frost, 314/85, EU:C:1987:452. 
to do so due to the unwillingness of the Supremo Tribunal de Justiça to make a reference for a preliminary ruling.

However, the scope of protection granted by the ECtHR is not necessarily sufficient because it is not within its competence to ensure the proper application of EU law. The Santos Pardal case provides such an example. As explained above, the ECtHR merely declared a violation on Article 6(1) ECHR for differing interpretations within the Supremo Tribunal de Justiça jurisprudence, neither fully acknowledging the impartiality issues raised, nor - and more importantly for the present purposes - the repercussions of the infringement of the obligation to make a reference for a preliminary ruling under Article 267(3) TFEU in the light of Article 6(1) ECHR. As regards to this point, the ECtHR considered that the Supremo Tribunal de Justiça had sufficiently motivated its decision not to refer to the ECJ for the interpretation of the Directive 90/232 «ne soulevait aucun doute vue la jurisprudence nationale au moment des faits» ${ }^{122}$. The ECtHR has been several times confronted with the failure of national courts adjudicating at last instance to make a reference for a preliminary ruling under Article 267(3) TFEU ${ }^{123}$. In the Santos Pardal case particularly, the assessement of the Strasbourg Court was rather short, low in intensity and arguably incorrect, as such an assessment is not to be made just on the basis of national case-law - as Ferreira da Silva latter emphasized. Thus, the observance of the Cilfit criteria to the effect of legitimately exempting the Supremo Tribunal de Justiça from its obligation to make a reference for a preliminary ruling under Article 267(3) TFEU was not properly assessed by the ECtHR and neither by the ECJ for lack of opportunity.

Only in recent decisions did the Strasbourg Court actually declare a violation of Article 6(1) ECHR arising from a decision of a national court adjudicating at last instance to not make a reference for a preliminary ruling for not being at all justified or not sufficiently justified within the conditions laid down in Cilfit ${ }^{124}$. This orientation, however, is yet to reach the Luxembourg Court. As a matter of fact, the Ferreira da Silva ruling is also a missing opportunity for the ECJ to interpret Article 267 TFEU, specially its paragraph 3, in light of Article 47 CFREU in a situation that highly recommended this reading, since the dispute in the main proceedings concerned the exercise of a right to compensation

122 Ferreira Santos Pardal v. Portugal (dec.), cit., note 106, part A, para 9.

123 See, inter alia, Ullens de Schooten and Rezabek v. Belgium, 20 September 2001, nos. 3989/07 and 38353/07, para 54-67, and Vergauwen and Others v. Belgium, 10 April 2012, no. 4832/04, para 87-92.

124 Dhahbi v. Italy, 8 April 2014, no. 17120/09, para 31-34, and Schipani and Others v. Italy, 21 July 2015, no. 38369/09, para 69-73. 
on a liability action brought against the State on the basis of a failure to comply with the obligation enshrined in the first provision.

Cases like Santos Pardal and Ferreira da Silva are, hopefully, exceptional cases. But exceptional situations like these test the limits of the legal provisions, and in particular the provisions of EU law, applicable to them. As follows from the above, when the loose ends left by Cilfit and Köbler are not adequately addressed at the national level in the light of EU law, the EU legal order fails to provide a remedy that meets the claims of individuals founded on EU law. Those are not ordinary cases because they ultimately relate to the exercise of a fundamental right: the right to an effective judicial remedy in the fields covered by EU law (Article 47 CFREU). This reveals a flaw within the Union system of protection of fundamental rights - that is, the lack of a specific proceeding or an «European rescue mechanism for fundamental rights» ${ }^{125}$ that could be triggered by individuals who are actively vigilant in protecting their rights when faced with the systematic unwillingness of the competent national courts to attend the questions of EU law at stake. Such a mechanism could be found taking further advantage of the possibilities already in existence within the EU system, such as the various possibilities for the individuals to address the Union institutions.

125 Viviane REDING, «Observations on the EU Charter of Fundamental Rights and the future of the European Union», XXV Congress of FIDE (Fédération Internationale pour le Droit Européen), Tallinn, 31 May 2012, available at europa.eu/rapid/pressrelease_SPEECH-12-403_en.htm?locale=en (accessed 28.6.2016). 